\title{
ICHNOLOGY OF A REWORKED STRANDPLAIN COMPLEX: MISSISSIPPIAN HARTSELLE SANDSTONE OF ALABAMA
}

\author{
RINDSBERG*, Andrew K., and PASHIN, Jack C., Geological Survey of Alabama, P.O. Box O, \\ Tuscaloosa, AL 35486-9780 U.S.A.
}

The Hartselle Sandstone of northern Alabama represents a mesotidal strandplain complex of Hombergian (middle Chesterian) age that was reworked by a transgressing sea. Transgressive reworking resulted in complex facies patterns that can best be deciphered by ichnology. Thickly bedded, unbioturbated beach to shoreface sandstone is widespread at the base of the formation. Wavy-bedded back-barrier to shelf sandstone and shale predominate in the middle and upper parts of the formation and contain distinctive assemblages of trace fossils, invertebrates, and plants.

Barriers with a broad, gently sloping beach face and muddy coastal swamps typified the Hartselle strandplain which extended across northern Alabama. Barrier and coastal-swamp deposits lack trace fossils but locally contain an indigenous lycopod flora including stumps and Stigmaria root systems.

Back-barrier tidal flats and lagoon deposits have trace-fossil assemblages dominated by bivalve traces that probably represent brackish environments. Marginal-marine sandstone contains chiefly monospecific assemblages and is reworked by bivalves and unknown organisms; Lockeia, Uchirites, and Rosselia are dominant at different sites. The Lockeia assemblage includes bedding surfaces with crowded bivalve resting traces. The abundance, density, and small size of monospecific burrows suggests estuarine conditions with high food supply and rapid larval colonization. The Uchirites assemblage is characterized by bivalve trails, representing probably brackish substrates with a high sedimentation rate.

Shelf sandstone and shale include bivalve resting traces and trails (Lockeia ispp., Uchirites isp. aff. $U$. triangularis, Walcottia rugosa, and W. imbricata), asteroid and ophiuroid resting traces (Asteriacites stelliforme and Pentichnus pratti), trilobite resting traces and trackways (Rusophycus ispp. and Petalichnus isp.), and dwelling burrows, feeding burrows, trails, and trackways of unknown organisms (Chondrites-like burrows, Phycodes isp., Haplotichnus isp., Rosselia isp., Planolites montanus, Nereites missouriensis, Tasmanadia twelvetreesi, imbricate burrows, and wavelike burrows). Some shclf areas even supported diverse calcified faunas containing crinoids, fenestrate bryozoans, and articulate brachiopods.

The Hartselle Sandstone is a facies mosaic that records indundation of an extensive strandplain complex and a distinctive stratigraphic succession of lithofacies and biofacies. Hartselle ichnofacies have unique aspects, but are similar to those of other marginal-marine Carboniferous strata in eastern North America. The paleoecologic complexity of the Hartselle Sandstone helps to establish the dynamic range of Carboniferous ecosystems, which have yet to be fully explored. 